\title{
Kualitas Fisik Pellet dengan Penambahan Level Tepung Daun Ubi Kayu serta Bahan Perekat yang Berbeda
}

\author{
Physical Quality of Pellets with Addition of Cassava Leaf Flour Level \\ and Different Binders
}

\section{Anwar Efendi Harahap ${ }^{1}$ dan Wieda Nurwidada Haritsah Zain ${ }^{2}$}

\author{
${ }^{1}$ Program Studi Peternakan Fakultas Pertanian dan Peternakan UIN Sultan Syarif Kasim Riau \\ Jl. H.R. Soebrantas No. 155 KM 15 Tuahmadani Tampan Pekanbaru 28293 \\ Corresponding e-mail: neniannisaharahap@yahoo.co.id
}

\begin{abstract}
One alternative that can be used for poultry feed is cassava flour (Manihot esculenta) which can be made into pellets. The purpose of this research was to know the physical quality of water content (KA), specific gravity (BJ), stack angle (ST), stack density (KT), stack compaction density (KPT), and impact resistance $(\mathrm{KB})$ of pellet product with utilization of flour cassava (Manihot esculenta). This research using Completely Randomized Design (RAL) Factorial. Factor A consisting of 3 treatments, that were A0: without adding cassava leaf flour, A1: 5\% and A2: $10 \%$ in ration formulation and Factor B consisting of 3 treatments binders, that were B0 : basal ration not binders, B1: tapioca starch and B2: wheat flour. The results showed that the interaction between the addition of cassava leaf flour and binders with different levels can be seen from water content, stack angle and stack compaction density, but on specific gravity, stack density and impact resistance did not occur interaction. It can be concluded that the addition of $10 \%$ cassava flour with tapioca flour binders gives the best quality of pellet physical properties to moisture content and stack angle, while other treatment combinations have not been able to improve pellet quality based on specific gravity, stack density, stack compaction density and impact resistance.
\end{abstract}

Keyword $s$ : Pellet, Cassava Leaf, Flour, Binders

\begin{abstract}
ABSTRAK
Salah satu alternatif yang dapat digunakan untuk pakan unggas adalah tepung ubi kayu (Manihot esculenta) yang dapat dibuat menjadi pelet. Tujuan penelitian ini adalah untuk mengetahui kualitas fisik Kadar Air (KA), Berat Jenis (BJ), Sudut Tumpukan (ST), Berat Jenis Tumpukan (KT), Berat Jenis Pemadatan Tumpukan (KPT), dan Ketahanan Dampak (KB). produk pelet dengan pemanfaatan tepung singkong (Manihot esculenta). Penelitian ini menggunakan Rancangan Acak Lengkap (RAL) Faktorial. Faktor A terdiri dari 3 perlakuan yaitu A0: tanpa penambahan tepung daun singkong, A1: 5\% dan A2: 10\% pada formulasi ransum dan Faktor B terdiri dari 3 perlakuan pengikat yaitu B0: ransum basal bukan pengikat, B1: tapioka pati dan B2: tepung terigu. Hasil penelitian menunjukkan bahwa interaksi antara penambahan tepung daun singkong dan bahan pengikat dengan kadar yang berbeda dapat dilihat dari kadar air, sudut tumpukan dan kepadatan pemadatan tumpukan, namun pada berat jenis, kepadatan tumpukan dan ketahanan benturan tidak terjadi interaksi. Dapat disimpulkan bahwa penambahan tepung ubi kayu $10 \%$ dengan bahan pengikat tepung tapioka memberikan kualitas sifat fisik pellet terbaik terhadap kadar air dan sudut tumpukan, sedangkan kombinasi perlakuan lainnya belum mampu meningkatkan kualitas pellet berdasarkan berat jenis, kepadatan tumpukan., kepadatan pemadatan tumpukan dan ketahanan benturan.
\end{abstract}

Kata Kunci: Pellet, Daun Singkong, Tepung, Pengikat

\section{PENDAHULUAN}

Ketersediaan bahan pakan di Indonesia tidak mencukupi kebutuhan peternakan yang ada, bahkan masih banyak bahan pakan yang di impor dari luar untuk kebutuhan produksi industri pakan yang ada. Hal ini menyebabkan tingginya harga pakan yang beredar dipasaran dan menyebabkan peternak harus mengeluarkan biaya produksi dalam jumlah besar. Biaya pakan 
merupakan komponen pengeluaran usaha pada usaha peternakan unggas, ternak harus diberi pakan dengan jumlah dan kualitas yang sesuai dengan kebutuhannya untuk bertumbuh, hal ini akan menyebabkan biaya pakan yang lebih tinggi.

Oleh karena itu, untuk menekan biaya pakan diperlukan mencari alternatif untuk bahan pakan sumber hijauan, yang ketersediaannya bahan pakan lokal yang melimpah salah satunya dengan memanfaatkan limbah perkebunan yaitu daun ubi kayu. Potensi daun ubi kayu di Provinsi Riau sangat melimpah dimana hasil panen pada tahun 2017 terdapat 3.578 hektar dengan produksi 345.67 ton (Badan Pusat Statistik, 2018). Tingginya potensi dari tanaman ubi kayu berimplikasi pada produksi limbah daun ubi kayu yang tinggi pula. Limbah daun ubi kayu dapat dijadikan sebagai bahan pakan sebagai ransum ternak, salah satunya pakan berbentuk pellet. Pellet adalah bentuk fisik pakan butiran yang diolah dengan metode pemadatan dan pencetakan pada mesin pelleter. Tujuan pemberian pakan pellet terutama pada ternak broiler adalah peningkatan kecernaan nutrisi terutama pada ternak broiler (Zalenka, 2003), peningkatan konsumsi pakan (Meinerz et al., 2001) serta mendukung pengeluaran energi yang lebih rendah dalam pemeliharaan dan meningkatkan ketersediaan energi bersih untuk produksi (Mckinney and Teeter, 2014). Ternak yang memperoleh pakan pellet memiliki kecenderungan performans yang lebih baik dan konversi pakan yang lebih rendah dibandingkan pakan mash. Keunggulan pakan bentuk pellet adalah (1) Bulk density (Kerapatan Tumpukan) pellet secara umum lebih tinggi, dibandingkan dengan pakan bentuk lain, sehingga daya angkut kendaraan akan lebih maksimal, (2) komposisi pellet relatif merata, karena pencampuran yang teliti, sehingga tidak ada segregasi (pemisahan) didalamnya. Pellet merupakan ransum berbentuk silinder atau tabung dengan diameter tertentu, atau berbentuk bulat mengandung nutrient lengkap yang diformulasikan sebelumnya untuk memenuhi kebutuhan ternak pada umumnya diperuntukkan untuk unggas. Retnani et al., (2011) menyatakan bahwa ransum crumble produk pellet berperekat tepung tapioka, onggok, dan bentonit memiliki pengaruh terhadap kadar air, aktivitas air, kerapatan tumpukan, kerapatan pemadatan tumpukan dan durability. Penelitian ini bertujuan mengkaji kualitas fisik pellet (kadar air, sudut tumpukan, kerapatan tumpukan, kerapatan padatan tumpukan dan ketahanan benturan) dengan penambahan berbagai level daun ubi kayu dalam ransum serta penambahan berbagai perekat yag berbeda.

\section{METODOLOGI}

\section{Materi Penelitian}

Bahan yang akan digunakan dalam pembuatan pellet adalah limbah daun ubi kayu, ransum konsentrat, jagung, dedak halus, tepung tapioka, tepung terigu sebagai bahan perekat pellet. Bahan untuk uji kualitas fisik pellet adalah sampel pellet dan Aquadest. Alat untuk membuat pellet

6 Kualitas Fisik Pellet dengan Penambahan Level ... 
adalah grinder, timbangan, alat tulis, sarung tangan, dan alat-alat yang mendukung selama penelitian. Alat untuk membuat pellet adalah saringan, baskom, timbangan, mesin pencetak pelleter (pellet) dan plastik. Alat untuk uji kualitas fisik adalah timbangan, cawan, oven, gelas ukur, penganduk, alat pengukur sudut tumpukan, corong, jangka sorong, tongkat kayu, lempeng besi, dan vibrator ballmill.

\section{Metode Penelitian}

Penelitian ini dilakukan secara eksperimen dengan menggunakan Rancangan Acak Lengkap (RAL) Faktorial (3x3) dengan 6 ulangan yang terdiri dari Faktor A dan Faktor B. Faktor A : Penambahan tepung daun ubi kayu dengan taraf:

$\mathrm{A}_{0}=$ Tanpa penambahan tepung daun ubi kayu.

$\mathrm{A}_{1}=$ Penambahan $5 \%$ tepung daun ubi kayu dalam formulasi ransum.

$\mathrm{A}_{3}=$ Penambahan $10 \%$ tepung daun ubi kayu dalam formulasi ransum.

Faktor B : Bahan perekat dengan 3 taraf perlakuan sebagai berikut:

$\mathrm{B}_{0}=$ Tanpa bahan perekat.

$\mathrm{B}_{1}=$ Bahan perekat dengan tepung tapioka.

$\mathrm{B}_{2}=$ Bahan perekat dengan tepung terigu.

\section{Prosedur Penelitian}

1. Persiapan bahan penelitian

Daun ubi kayu yang digunakan adalah limbah dari perkebunan daun ubi kayu yang tidak digunakan lagi setelah ubi kayu dipanen. Daun ubi kayu dijemur di bawah sinar matahari sampai kering, selanjutnya daun ubi kayu digrinder untuk dijadikan tepung. Kemudian daun ubi kayu ditimbang sesuai dengan kebutuhan perlakuan.

\section{Proses pembuatan Pellet}

Sebelum dilakukan pembuatan pellet semua bahan-bahan pakan ditimbang sesuai dengan formulasi ransum yang telah di susun. Setelah itu di jadikan adonan dengan menambahkan air secukupnya dan di cetak dengan mesin pellet (pelleting), lalu dijemur dibawah sinar matahari sampai kering.

3. Uji kualitas fisik pellet

Sampel yang telah didinginkan dilakukan uji fisik di Laboratorium Agrostologi, Industri Pakan dan Ilmu Tanah Fakultas Pertanian dan Peternakan UIN Sultan Syarif Kasim Riau.

\section{Parameter Penelitian}

Parameter penelitian ini adalah : kadar air (\%), sudut tumpukan $\left(^{0}\right)$, kerapatan tumpukan $\left(\mathrm{g} / \mathrm{cm}^{3)}\right.$, kerapatan padatan tumpukan $\left(\mathrm{g} / \mathrm{cm}^{3}\right)$ dan ketahanan benturan $(\%)$. 
Selanjutnya ransum pellet yang digunakan untuk pemeliharaan ternak broiler. Komposisi nutrisi bahan pakan, formulasi ransum dan kandungan perlakuan ransum perlakuan dapat dilihat pada Tabel 1:

Tabel 1. Komposisi Nutrisi Bahan Pakan

\begin{tabular}{lcccccc}
\hline \multirow{2}{*}{ Bahan Pakan } & \multicolumn{7}{c}{ Komposisi Nutrisi Bahan Pakan } \\
\cline { 2 - 7 } & $\begin{array}{c}\text { Protein } \\
\text { Kasar }(\%)\end{array}$ & $\begin{array}{c}\text { Energi } \\
\text { Metabolisme } \\
(\text { Kkal/kg) }\end{array}$ & $\begin{array}{c}\text { Lemak } \\
\text { Kasar }(\%)\end{array}$ & $\begin{array}{c}\text { Serat } \\
\text { Kasar }(\%)\end{array}$ & Ca & P \\
\hline Jagung & 9,00 & 3350,00 & 2,50 & 2,00 & 0,05 & 0,31 \\
Dedak Halus & 8,15 & 3000,00 & 6,50 & 21,80 & 0,14 & 0,60 \\
TDUK* & 24,10 & 2590,00 & 4,73 & 22,10 & 1,54 & 0,45 \\
Konsentrat & 39,9 & 2641,00 & 5,07 & 2,03 & 0,63 & 0,01
\end{tabular}

Sumber: Laboratorium Ilmu dan Teknologi Pakan Fakultas IPB, 2000 dan Laboratorium Nutrisi dan Kimia Fapertapet UIN Suska Riau 2015.

* Departemen Nutrisi dan Teknologi Pakan, Fakultas Peternakan IPB Bogor 2015.

TDUK = Tepung Daun Ubi Kayu

Tabel 2. Susunan Perlakuan Penelitian

\begin{tabular}{lccc}
\hline \multirow{2}{*}{ Nama Bahan } & \multicolumn{3}{c}{ Perlakuan } \\
\cline { 2 - 4 } & $\mathrm{R} 0$ & $\mathrm{R} 1$ & $\mathrm{R} 2$ \\
\hline Jagung & 50,00 & 53,00 & 51,00 \\
Dedak Halus & 22,00 & 16,00 & 15,00 \\
Tepung Daun Ubi Kayu & 0,00 & 5,00 & 10,00 \\
Konsentrat & 28,00 & 26,00 & 24,00 \\
\hline Total & 100,00 & 100,00 & 100,00 \\
\hline
\end{tabular}

Tabel 3. Kandungan Nutrisi Perlakuan Ransum Broiler

\begin{tabular}{ccccccc}
\hline \multirow{2}{*}{ Perlakuan } & \multicolumn{7}{c}{ Kandungan Nutrisi } \\
\cline { 2 - 7 } & $\begin{array}{c}\text { Protein } \\
\text { Kasar }(\%)\end{array}$ & $\begin{array}{c}\text { Energi } \\
\text { Metabolisme } \\
(\mathrm{kkal} / \mathrm{Kg})\end{array}$ & $\begin{array}{c}\text { Lemak } \\
\text { Kasar }(\%)\end{array}$ & $\begin{array}{c}\text { Serat Kasar } \\
(\%)\end{array}$ & $\mathrm{Ca}$ & $\mathrm{P}$ \\
\hline R0 & 17,47 & 3074,48 & 4,10 & 6,36 & 0,23 & 0,29 \\
R1 & 17,65 & 3071,56 & 3,92 & 6,08 & 0,29 & 0,29 \\
R2 & 17,80 & 3011,34 & 3,94 & 6,99 & 0,35 & 0,30 \\
\hline
\end{tabular}

Ket: Disusun berdasarkan Tabel 3.1 dan Tabel 3.2.

\section{Analisis Data}

Rancangan yang digunakan dalam penelitian ini adalah Rancangan Acak Lengkap (RAL) Faktorial (3x3) dengan 6 ulangan (Steel dan Torrie, 1995). Model matematik analisis ragam adalah sebagai berikut:

$$
Y_{i j k}=\mu+\alpha_{i}+\beta_{j}+(\alpha \beta)_{i j}+\varepsilon_{i j k}
$$




\section{Kadar Air}

\section{HASIL DAN PEMBAHASAN}

Nilai rataan kadar air pakan pellet ternak dapat dilihat pada Tabel dibawah ini Tabel 1. Nilai Rataan Kadar Air Pakan Pellet (\%).

\begin{tabular}{ccccc}
\hline Faktor A Tepung & \multicolumn{3}{c}{ Faktor B (Bahan Perekat) } & \multirow{2}{*}{ Rataan } \\
\cline { 2 - 4 } Daun Ubi Kayu & TBP & T. Terigu & T. Tapioka & \\
\hline $0 \%$ & $8,59 \pm 3,22^{\mathrm{aA}}$ & $7,67 \pm 2,08^{\mathrm{aA}}$ & $13,26 \pm 1,83^{\mathrm{bC}}$ & $9,84 \pm 2,37$ \\
$5 \%$ & $9,76 \pm 5,09^{\mathrm{aA}}$ & $8,55 \pm 1,74^{\mathrm{aA}}$ & $9,80 \pm 2,98^{\mathrm{aB}}$ & $9,37 \pm 3,27$ \\
$10 \%$ & $8,12 \pm 1,18^{\mathrm{aA}}$ & $7,26 \pm 1,10^{\mathrm{aA}}$ & $6,29 \pm 0,91^{\mathrm{aA}}$ & $7,22 \pm 1,07$ \\
\hline Rataan & $8,82 \pm 3,23$ & $7,83 \pm 1,65$ & $9,78 \pm 1,91$ & \\
\hline
\end{tabular}

Keterangan: Data adalah Rataan \pm Standar Deviasi

Superskrip yang berbeda pada baris (huruf kecil) dan kolom (huruf besar) yang sama menunjukkan perbedaan sangat nyata $(\mathrm{P}<0,01)$

TBP: tanpa bahan perekat.

Penambahan tepung daun ubi kayu berpengaruh sangat nyata $(\mathrm{P}<0,01)$ terhadap kadar air pellet yang dihasilkan, hal ini diduga karena analisis awal kadar air yang dimiliki oleh tepung daun ubi kayu sebesar 10,28, setelah proses pencetakan pellet kadar air relatif turun. Hal ini sesuai dengan Syarief dan Halid (1994) bahwa kadar air adalah banyaknya kandungan air dalam bahan berdasarkan berat kering yang dipengaruhi oleh jenis bahan, suhu dan kelembaban lingkungan. Penambahan bahan perekat yang berbeda dalam formulasi ransum tidak berpengaruh nyata $(\mathrm{P}>0,05)$ terhadap kadar air pellet ternak yang dihasilkan. Hal ini diduga karena partikel bahan, proses pencetakan yang mempunyai suhu yang digunakan juga sama sehingga pembentukan gel antara semua perekat yang dihasilkan relatif sama, sehingga kadar air yang dihasilkan juga tidak berbeda. Interaksi antara tepung daun ubi kayu dan bahan perekat yang berbeda dalam formulasi ransum memberikan pengaruh nyata $(\mathrm{P}<0,05)$, kandungan kadar air pellet berkisar antara 6,2913,26\%. Kombinasi perlakuan $0 \%$ tepung daun ubi kayu dan penggunaan tepung tapioka menghasilkan kadar air yang lebih tinggi dibandingkan perlakuan lainnya. Hal ini diduga karena ukuran partikel yang memiliki kandungan serat kasar yang cukup tinggi, sehingga berpengaruh terhadap kadar air. Hasil penelitian ini lebih rendah Berdasarkan Standar Nasional Indonesia (SNI) bahwa kadar air maksimum 14\% (Direktorat Bina Produksi, 1997). Penelitian ini hampir sama dengan penelitian Nurhayatin dan Puspitasari (2017) pada pakan pellet dengan berbagai pengolahan binder pati garut yang disimpan hingga 45 hari menghasilkan kadar air berkisar antara $8,87-9,35 \%$ 


\section{Kerapatan Tumpukan}

Nilai rataan kerapatan tumpukan pakan pellet dapat dilihat pada Tabel 2.

Tabel 2. Nilai Rataan Kerapatan Tumpukan Pakan Pellet $\left(\mathrm{g} / \mathrm{cm}^{3}\right)$.

\begin{tabular}{ccccc}
\hline Faktor A & \multicolumn{3}{c}{ Faktor B (Bahan Perekat) } & \multirow{2}{*}{ Rataan } \\
\cline { 2 - 4 } Ubi Kayu & TBP & T. Terigu & T. Tapioka & \\
\hline $0 \%$ & $0,36 \pm 0,00$ & $0,35 \pm 0,01$ & $0,35 \pm 0,21$ & $0,35 \pm 0,07$ \\
$5 \%$ & $0,35 \pm 0,01$ & $0,36 \pm 0,01$ & $0,35 \pm 0,01$ & $0,35 \pm 0,01$ \\
$10 \%$ & $0,34 \pm 0,01$ & $0,36 \pm 0,01$ & $0,37 \pm 0,21$ & $0,36 \pm 0,07$ \\
\hline Rataan & $0,35 \pm 01$ & $0,36 \pm 0,01$ & $0,36 \pm 0,14$ & \\
\hline
\end{tabular}

Keterangan: Data adalah Rataan \pm Standar Deviasi

TBP : tanpa bahan perekat.

Level penambahan tepung daun ubi kayu dalam formulasi ransum yang dihasikan tidak berpengaruh nyata $(\mathrm{P}>0,05)$ terhadap kerapatan tumpukan pellet yang dihasilkan, hal ini kemungkinan disebabkan karena ukuran partikel bahan yang digunakan sama sehingga menyebabkan kerapatan tumpukan pada pellet tidak stabil dan berhubungan erat dengan sifat fisik berat jenis, hal ini sesuai dengan pendapat (Kling dan Wohlebier, 1983 dalam Khalil 1999a) bahwa kerapatan tumpukan berpengaruh terhadap daya campur dan ketelitian penakaran penggunaan ransum. Penambahan bahan perekat yang berbeda dalam formulasi ransum pellet yang dihasilkan tidak memberikan pengaruh yang nyata $(\mathrm{P}>0,05)$ terhadap kerapatan tumpukan pellet. Hal ini kemungkinan diduga karena tingkat kehalusan bahan perekat dengan bahan formulasi ransum yang sama, hal ini didukung oleh Khalil (1999a) bahwa kerapatan tumpukan ransum penelitian dipengaruhi oleh perbedaan ukuran partikel, kadar kehalusan dan persentase pellet utuh sehingga menyebabkan perbedaan tingkatan pemadatan volume. Hasil penelitian ini lebih rendah $\left(0,34 \mathrm{~g} / \mathrm{cm}^{3}-0,37 \mathrm{~g} / \mathrm{cm}^{3}\right)$ dibandingkan dengan hasil penelitian yang dilakukan oleh Akbar $d k k$. (2017) pada pakan pellet dengan penambahan mengkudu dalam ransum yang disimpan selam 6 minggu menghasilkan kerapatan tumpukan dengan rataan $0,66 \mathrm{~g} / \mathrm{cm}^{3}-0,69 \mathrm{~g} / \mathrm{cm}^{3}$

\section{Kerapatan Pemadatan Tumpukan}

Nilai rataan kerapatan pemadatan tumpukan pakan pellet dapat dilihat pada Tabel 3. Tabel 3 Nilai Rataan Kerapatan Pemadatan Tumpukan Pakan Pellet $\left(\mathrm{g} / \mathrm{cm}^{3}\right)$.

\begin{tabular}{|c|c|c|c|c|}
\hline \multirow{2}{*}{$\begin{array}{c}\text { Faktor A } \\
\text { Tepung Daun } \\
\text { Ubi Kayu }\end{array}$} & \multicolumn{3}{|c|}{ Faktor B (Bahan Perekat) } & \multirow[b]{2}{*}{ Rataan } \\
\hline & TBP & T. Terigu & T. Tapioka & \\
\hline $0 \%$ & $0,38 \pm 0,01^{\mathrm{aA}}$ & $0,38 \pm 0,01^{\mathrm{aA}}$ & $0,38 \pm 0,01^{\mathrm{aA}}$ & $0,38 \pm 0,01$ \\
\hline $5 \%$ & $0,37 \pm 0,01^{\mathrm{aA}}$ & $0,37 \pm 0,01^{\mathrm{Aa}}$ & $0,37 \pm 0,02^{\mathrm{aA}}$ & $0,37 \pm 0,01$ \\
\hline $10 \%$ & $0,36 \pm 0,01^{\mathrm{aA}}$ & $0,37 \pm 0,01^{\mathrm{abA}}$ & $0,39 \pm 0,01^{\mathrm{bA}}$ & $0,38 \pm 0,01$ \\
\hline Rataan & $0,37 \pm 0,01$ & $0,37 \pm 0,01$ & $0,38 \pm 0,01$ & \\
\hline Keterangan: & $\begin{array}{l}\text { lah Rataan } \pm \text { Stan } \\
\text { huruf yang berbec } \\
\text { nyata }(\mathrm{P}<0,05) \\
\text { oa bahan perekat. }\end{array}$ & $\begin{array}{l}\text { viasi } \\
\text { baris (huruf keci }\end{array}$ & huruf besar) & unjukkan \\
\hline
\end{tabular}


Level penambahan tepung daun ubi kayu dalam formulasi ransum tidak berpengaruh nyata $(\mathrm{P}>0,05)$ terhadap kerapatan pemadatan tumpukan pellet, hal ini diduga karena ukuran partikel setiap bahan formulasi pada perlakuan ransum yang tidak berbeda terutama pada bahan pakan tepung daun ubi kayu yang memiliki kandungan serat kasar, hal ini sesuai dengan yang dilaporkan oleh Sayekti (1999) bahwa kerapatan pemadatan tumpukan dipengaruhi oleh ukuran partikel bahan baku. Penambahan bahan perekat yang berbeda dalam formulasi ransum pellet tidak memberikan pengaruh yang nyata $(\mathrm{P}>0,05)$ terhadap kerapatan pemadatan tumpukan pellet. Hal ini diduga karena tingkat kehalusan bahan perekat dengan bahan formulasi ransum yang relatif sama, hal ini sesuai yang dilaporkan oleh Khalil (1999a) bahwa kerapatan pemadatan tumpukan ransum penelitian dipengaruhi oleh perbedaan ukuran partikel, kadar kehalusan dan persentase pellet utuh sehingga menyebabkan perbedaan tingkatan pemadatan volume. Interaksi antara penambahan tepung daun ubi kayu dengan bahan perekat yang berbeda memberikan pengaruh nyata $(\mathrm{P}<0,05)$ terhadap kerapatan pemadatan tumpukan yang dihasilkan. Hal ini menunjukkan semakin tinggi nilai kerapatan pemadatan tumpukan maka nilai kerapatan tumpukan juga akan meningkat. Sesuai dengan pernyataan Luciana (2012) kerapatan pemadatan tumpukan dan kerapatan tumpukan pelet ransum komplit berkorelasi positif, semakin tinggi nilai kerapatan tumpukan maka nilai kerapatan pemadatan tumpukan akan semakin tinggi dan sebaliknya.. Hasil penelitian ini lebih rendah $\left(0,357 \mathrm{~g} / \mathrm{cm}^{3}\right)$ dibandingkan hasil penelitian Jaelani $d k k$., 2016 yaitu pakan pellet yang disimpan dengan lama (0-13 hari) dan perbedaan tumpukan menghasilkan kerapatan pemadatan tumpukan $0,65 \mathrm{~g} / \mathrm{cm}^{3}-0,69 \mathrm{~g} / \mathrm{cm}^{3}$

\section{Sudut Tumpukan}

Nilai rataan sudut tumpukan pakan pellet dapat dilihat pada Tabel 4.

Tabel 4. Nilai Rataan Sudut Tumpukan Pakan Pellet $\left({ }^{\circ}\right)$.

\begin{tabular}{ccccc}
\hline Faktor A Tepung & \multicolumn{3}{c}{ Faktor B (Bahan Perekat) } & \multirow{2}{*}{ Rataan } \\
\cline { 2 - 4 } Daun Ubi Kayu & TBP & T. Terigu & T. Tapioka & \\
\hline $0 \%$ & $49,65 \pm 2,68^{\mathrm{bA}}$ & $44,51 \pm 3,17^{\mathrm{aB}}$ & $43,46 \pm 2,17^{\mathrm{aA}}$ & $45,87 \pm 2,67$ \\
$5 \%$ & $47,78 \pm 1,83^{\mathrm{bA}}$ & $41,84 \pm 1,53^{\mathrm{aA}}$ & $45,90 \pm 1,95^{\mathrm{bB}}$ & $45,19 \pm 1,77$ \\
$10 \%$ & $47,49 \pm 2,03^{\mathrm{aA}}$ & $45,16 \pm 1,50^{\mathrm{aB}}$ & $45,53 \pm 1,65^{\mathrm{aAB}}$ & $46,06 \pm 1,73$ \\
\hline Rataan & $48,30 \pm 2,18$ & $43,84 \pm 2,07$ & $44,96 \pm 1,92$ & \\
\hline
\end{tabular}

Keterangan: Data adalah Rataan \pm Standar Deviasi

Superskrip yang berbeda pada baris (huruf kecil) dan kolom (huruf besar) yang sama menunjukkan perbedaan sangat nyata $(\mathrm{P}<0,01)$

TBP: tanpa bahan perekat.

Level penambahan tepung daun ubi kayu yang berbeda dalam formulasi ternak unggas yang dihasilkan tidak berpengaruh nyata $(\mathrm{P}>0,05)$ terhadap sudut tumpukan pellet, hal ini disebabkan oleh pengaruh kadar air dan ukuran partikel bahan yang relatif sama, sehingga sudut tumpukan yang dihasilkan tidak berbeda. Hal ini sesuai dengan pendapat Sholihah (2011) bahwa semakin 
tinggi kadar air menyebabkan berat jenis, kerapatan tumpukan, kerapatan pemadatan tumpukan dan Pellet Durability Index rendah serta nilai sudut tumpukan yang besar. Penambahan bahan perekat yang berbeda dalam formulasi ransum pellet yang dihasilkan memberikan pengaruh yang sangat nyata $(\mathrm{P}<0,01)$ terhadap sudut tumpukan pellet. Hal ini diduga karena tepung terigu dan tepung tapioka memiliki kandungan pati, sehingga proses penetrasi air dan panas secara bersamaan kedalam granula pati menyebabkan pengembangan granula. Interaksi antara penambahan tepung daun ubi kayu dengan bahan perekat yang berbeda memberikan pengaruh nyata $(\mathrm{P}<0,05)$ terhadap sudut tumpukan, hal ini diduga dipengaruhi oleh kadar air dan ukuran partikel kecil/ halus. Hasil penelitian ini lebih tinggi $\left(41,84^{\circ}-49,65^{\circ}\right)$ dibandingkan hasil penelitian Akbar dkk., (2017) pada pakan pellet dengan penambahan tepung daun mengkudu dalam ransum serta penyimpanan hingga minggu ke 6 menghasilkan sudut tumpukan berkisar $\operatorname{antara} 13,87^{\circ}-17,7^{\circ}$

\section{Ketahanan Benturan}

Nilai rataan ketahanan benturan pakan pellet dapat dilihat pada Tabel 6.

Tabel 6. Nilai Rataan Ketahanan Benturan Pakan Pellet Ternak Unggas (\%).

\begin{tabular}{ccccc}
\hline Faktor A & \multicolumn{3}{c}{ Faktor B (Bahan Perekat) } & \multirow{2}{*}{ Rataan } \\
\cline { 2 - 4 } $\begin{array}{c}\text { Tepung Daun } \\
\text { Ubi Kayu }\end{array}$ & TBP & T. Terigu & T. Tapioka & \\
\hline $0 \%$ & $86,12 \pm 0,23$ & $85,52 \pm 0,80$ & $84,91 \pm 3,00$ & $85,52 \pm 1,36$ \\
$5 \%$ & $85,82 \pm 1,15$ & $82,29 \pm 3,13$ & $85,89 \pm 0,67$ & $84,67 \pm 1,65$ \\
$10 \%$ & $86,00 \pm 0,64$ & $84,03 \pm 4,07$ & $86,17 \pm 0,18$ & $85,42 \pm 1,63$ \\
\hline Rataan & $86,00 \pm 0,69^{\mathrm{B}}$ & $83,94 \pm 2,66^{\mathrm{A}}$ & $85,66 \pm 1,28^{\mathrm{B}}$ & \\
\hline
\end{tabular}

Keterangan: $\quad$ Data adalah Rataan \pm Standar Deviasi

Superskrip huruf yang berbeda pada baris yang sama (huruf besar) menunjukkan perbedaan sangat nyata $(\mathrm{P}<0,01)$

TBP : tanpa bahan perekat.

Level pemberian tepung daun ubi kayu yang berbeda dalam formulasi ransum pellet ternak unggas tidak memberikan pengaruh nyata $(\mathrm{P}>0,05)$ terhadap ketahanan benturan pellet, hal ini diduga karena ukuran partikel formulasi ransum berbeda terutama pada bahan pakan tepung daun ubi kayu yang relatif sama sehingga berimplikasi terhadap tidak berbedanya ketahanan benturan yang dihasilkan, hal ini sesuai dengan yang dilaporkan oleh (Thomas et al., 1997) bahwa kandungan bahan yang mempengaruhi ketahanan benturan pellet adalah pati, gula, protein, serat kasar dan lemak. Penambahan bahan perekat yang berbeda dalam formulasi ransum pellet yang dihasilkan memberikan pengaruh yang sangat nyata $(\mathrm{P}<0,01)$ terhadap ketahanan benturan pellet. Hal ini diduga perlakuan perekat tepung tapioka mempunyai pati yang stabil dibandingkan dengan perekat lainnya, hal ini sesuai dengan McElhiney (1994) faktor- faktor yang mempengaruhi ketahanan benturan adalah: 1) karakter bahan baku, dalamhal ini faktor yang dimaksud adalah 
protein, lemak, serat, pati, density (kepadatan), tekstur dan air, serta kestabilan karakteristik bahan akan menghasilkan kualitas pellet yang baik. Hasil penelitian ini lebih rendah dibandingkan dengan hasil penelitian Retnani $d k k$., (2011) pada pakan broiler berbentuk crumble hasil produk pellet dengan penambahan bahan perekat tepung tapioka, bentonit dan onggok dengan nilai ketahanan benturan berkisar antara 98,00 - 98,92\%

\section{KESIMPULAN}

Penambahan tepung daun ubi kayu 10\% dengan bahan perekat tepung tapioka memberikan kualitas sifat fisik pellet yang terbaik terhadap kadar air dan sudut tumpukan, sedangkan kombinasi perlakuan lainnya belum bisa memperbaiki kualitas pellet berdasarkan kerapatan tumpukan, kerapatan pemadatan tumpukan dan ketahanan benturan.

\section{DAFTAR PUSTAKA}

Akbar, M.RL., D.M. Suci dan I. Wijayanti. 2017. Evaluasi kualitas pellet pakan itik yang disuplementasi tepung daun mengkudu (Morinda citrifolia) dan disimpan selama 6 minggu. Buletin Makanan Ternak. 104 (2): 31-48

Jaelani A., Siti. D dan Wacahyono. 2016. Pengaruh tumpukan dan lama masa simpan pakan pelet terhadap kualitas fisik. Ziraa'ah. 41(2):261- 268

Khalil. 1999a. Pengaruh kandungan air dan ukuran partikel terhadap perubahan perilaku fisik bahan pakan lokal: Kerapatan Tumpukan, Kerapatan Pemadatan Tumpukan dan Berat Jenis. Media Peternakan, 22(1): 1-11.

Kling, M and W. Wohlbier. 1983. Handels Futtermitter, Band 2A. Verlag Eugen Ulmer. Stuttgart.

Luciana, D.Y. 2012. Uji Kualitas Sifat Fisik dan Daya Simpan Pellet yang Mengandung Klobot Jagung dan Limbah Tanaman Ubi Jalar sebagai Substitusi Daun Rumput Gajah. Skripsi. Fakultas Peternakan. Institut Pertanian Bogor. Bogor.

Meinerz, C., Ribeiro, A. M. L., Penz Jr, A. M., and Kessler, A. M. 2001. "Energy Level and Pelleting on Performance and Carcass Yield of Pair-Fed Broilers." Brazilian Journal of Animal Science 30 (6): 2026-32.

McElhiney, R. R. 1994. Feed Manufacturing Technology IV. American Feed Industry Association, Inc. Arlington, Virginia.

Nurhayatin, T. dan M. Puspitasari. 2017. Pengaruh cara pengolahan pati garut (aranta arundinacea) sebagai binder dan lama penyimpanan terhadap kualitas fisik pellet ayam broiler. Jurnal of Animal Husbandry Science. 2 (1): 32-40

Mckinney, L. J., and Teeter, R. G. 2004. "Predicting Effective Caloric Value of Nonnutritive Factors: Part I, Pellet Quality and Part II, Prediction of Consequential Formulation Dead Zones." Poultry Science 83 (7): 1165-74.

Retnani Y., L. Herawati., dan S. Kusniati. 2011. Uji sifat fisik ransum broiler starter bentuk crumble berperekat tepung tapioka, bentonit dan onggok. JITV. 1(2): 88-97 
Retnani Y., Putra E.D., dan L. Herawati. 2011. Pengaruh taraf penyemprotan air dan lama penyimpanan terhadap daya tahan ransum broiler finisher berbentuk pellet. Agripet, 11(1), $10-14$

Sayekti, W. B. R. 1999. Karakteristik sifat fisik berbagai varietas jagung (Zea mays). Skripsi. Fakultas Peternakan. Institut Pertanian Bogor.Bogor.

Sholihah, U. I. 2011. Pengaruh Diameter Pelet dan Lama Penyimpanan Terhadap Kualitas Fisik Pelet Daun Legume Indigofera sp. Skripsi. Fakultas Peternakan. Institut Pertanian Bogor. Bogor.

Steel, R. G. D and J. H. Torrie. 1995. Prinsip dan Prosedur Statistik. Terjemahan : B. Sumantri. PT Gramedia Pustaka Utama, Jakarta.

Syarief, R dan H. Halid. 1994. Teknologi Penyimpanan Pakan. Penerbit Arcan. Jakarta.

Thomas, M and A.F.B. Van der Poel. 1997. Physical quality of pelleted animal feed contribution of processes and its condition. J. Animal Feed Science and Technology. 64(2): 173-192.

Zalenka, J. 2003. "Effect of Pelleting on Digestibility and Metabolizable Energy of Poultry Diets." In Proceedings of European Symposium on Poultry Nutrition, 127-8. 